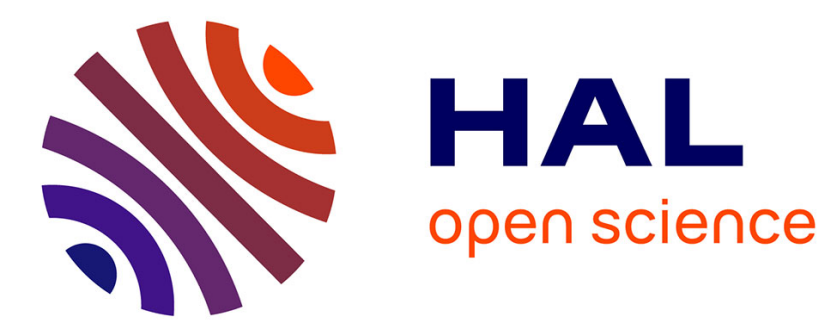

\title{
Win some, lose some: genome evolution in red algae Jonas Collén
}

\section{To cite this version:}

Jonas Collén. Win some, lose some: genome evolution in red algae. Journal of Phycology, 2015, 51 (4), pp.621-623. 10.1111/jpy.12324 . hal-01190779

\section{HAL Id: hal-01190779 https://hal.sorbonne-universite.fr/hal-01190779}

Submitted on 1 Sep 2015

HAL is a multi-disciplinary open access archive for the deposit and dissemination of scientific research documents, whether they are published or not. The documents may come from teaching and research institutions in France or abroad, or from public or private research centers.
L'archive ouverte pluridisciplinaire HAL, est destinée au dépôt et à la diffusion de documents scientifiques de niveau recherche, publiés ou non, émanant des établissements d'enseignement et de recherche français ou étrangers, des laboratoires publics ou privés. 
Win some, lose some: genome evolution in red algae.

Jonas Collén

Sorbonne Universités, UPMC Univ Paris 06, UMR 8227, Integrative Biology of Marine Models, Station Biologique de Roscoff, Sorbonne Universités, CS 90074, F-29688 Roscoff cedex, France

CNRS, UMR 8227, Integrative Biology of Marine Models, Station Biologique de Roscoff, CS 90074, F29688 Roscoff cedex, France

What's special about red algae? You might say that they have distinct pigments, the phycobiliproteins; unusual plastids with unstacked thylakoids; a different storage saccharide, floridean starch; or that some species have a unique triphasic life history and a special connection between cells, pit plugs. To me, what is most fascinating is what they don't have. There are no flagella and no centrioles. What is the result of not having a flagella? One think that it means is that at no stage in the life cycle can the organism swim. Red algae are, thus, aquatic organisms that sexually reproduce, but with only extremely limited possibilities with respect to chemotaxic responses toward gametes of the other sex, complicating the fusion of gametes. For example, in red algae the male gametes are released and have to, by random movement of waves and currents, find a female gamete on a female plant; remember that the ocean is big and not covered with red algae and that there are many species. A lack of motility also means that unicellular planktonic red algae have a decreased capability to position themselves in the light environment. It is generally believed that the ancestral eukaryote had a flagellum (Koumandou et al. 2013), and therefore it must have been lost in red algae. Therefore, the flagella along with the capacity for directed movement, except limited ( $<1 \mathrm{~mm}$ ) amoebic movement (Pickett-Heaps et al. 2001), have disappeared. This is likely to be a large handicap for red algae, suggesting that the evolutionary force that triggered the loss of flagella was very strong. So what happened, when and why? The answers to these questions have for a long time been a mystery, but recent increased knowledge on genes and genomes of red algae is starting to shed some light on this subject and on the general evolution of red algal genes and genomes. The article by Qui et al. (2015) in this issue provides new, important insights into the evolution of red algal genomes, including the loss of genes, the loss of function, and the subsequent gain of genes through horizontal gene transfer.

Qui et al (2015) analyzed existing genomes from extremophilic unicellular (Galdieria sulphuraria, Cyanidioschyzon merolae and Cyanidium caldarium) and mesophilic uni- and multicellular red algae (Porphyridium purpureum, Chondrus crispus, Calliarthron tuberculosum, and Pyropia yezoensis) along with a number of transcriptomes and, assuming a common ancestor of red algae and the green lineage, they deduced when genes and groups of genes disappeared. The red algae appear to have experienced two prominent occasions of gene loss. One occurred before the split between Cyanidiophytina and the other red algae, $\sim 1.5 \mathrm{Ga}$ (Yoon et al. 2004) with a loss of $25 \%$ of the genes. The other occurred within the Cyanidiophytina, after $1.4 \mathrm{Ga}$, with a loss of an additional $25 \%$ of the genes. 
We knew beforehand that red algae lacked flagella as well as phytochrome photoreceptors. How about the genes that code for these functions? Are they all lost and is the pattern of gene loss similar in other organisms, that have lost the flagellum? The authors compared genes of photosynthetic organisms from different lineages (red algae, land plants, and specific groups of green algae and diatoms), either flagellate (e.g. Ectocarpus siliculosus, Cyanophora paradoxa, Physcomitrella patens and Chlorella variabilis) or nonflagellate, involved in flagellar function. Qui et al show that the loss of the flagellum results in similar gene losses in disparate organisms. The selective advantage of losing a flagella could be that the biogenesis of this structure requires many genes (over 300) and while its function consumes high amounts of energy. With the absence of flagella you can also eliminate genes encoding proteins that would regulate movement, like phytochromes, although phytochromes may also have additional roles, including in photomorphogenesis and the regulation of genes involved in photosynthesis. Flagella in eukaryotes also often have sensory functions (Bloodgood 2010), and elimination of flagella implies the loss of sensory information, but it also obviates the need for genes required for processing and responding to this information. Maybe this explains why the loss of flagella has occurred many times in evolution; if you can function without them large energetic gains are possible. The loss of flagella is not uncommon in evolution; in addition to the red algae, most fungi and many amoebae lost the capacity to make a flagella (Moran et al. 2014).

What other genes were lost? The authors searched for pathways that had disappeared from red algae. All 22 genes important for glycosyl-phosphatidylinositol (GPI) anchor biosynthesis, 17 genes in the autophagy pathway, and 3 genes in pyrimidine degradation are absent in red algae. All three pathways occur in most eukaryotes and often mutations in these genes are lethal. This result indicates that several important pathways were lost or sacrificed during the evolution of red algae. We should also keep in mind that for half of the genes in red algae and other organisms we have no idea of function, and therefore no idea what functions were lost or retained.

Loss because of constraints, whatever they might have been, might make it advantage to regain certain gene functions through processes such as horizontal gene transfer. To test for this, the authors used their dataset to identify non-cyanobacterial horizontal gene transfer and found 200-400 candidates present in one or more of the red algal genomes. This gene set encodes phosphoenolpyruvate carboxykinase, catalase, and phosphoenolpyruvate synthase, among others. There were also genes that were present in both Cyanidiophytina and Rhodophytina, representing probable early horizontal transfers; these include genes encoding a magnesium transporter, a carbamoyl transferase, and a ubiquinone biosynthesis methyltransferase. Some of these newly introduced genes probably replaced genes already present on the genome, while others may reflect a regaining of gene functions. These findings highlight the importance of genome fluidity in the evolution of red algae.

While the authors are prudent with their speculations, I will allow myself more liberties. I think the finding that the ancestral red algal genome was reduced can help explain both 1) why trees are green and 2) why aquatic photosynthesis is "brown". First, why is terrestrial photosynthesis dominated by organisms of green algal origin... why not red trees and grass? In the temperate intertidal zone and in fresh waters, there are both green and red algae. However, there are virtually no terrestrial red algae (Hoffman 1989). Instead, all terrestrial plants belong to green lineage. Why did the red lineage not evolve to be terrestrial? Maybe the drastic reduction of genes in the ancestral red alga reduced the available genetic resources necessary to conquer the land. It is not only the flagellar genes that were 
lost, which would later disappear also in embryophytes, but also many other genes, often of unknown function, that might have helped initiate movement into terrestrial habitats. Perhaps this reduced genetic diversity made it impossible, or much more difficult, for red algae to become flowering plants and trees and, thus, the loss of genes over a billion years ago made our planet green instead of red.

My second speculation concerns why red algae are not an important part of the phytoplankton; planktonic species exist, but are neither very diverse nor common. The lack of swimming would be an unfavorable fitness trait for plankton and, thus, not having a flagellum would create a grave disadvantage for red phytoplankton. In addition, according to Dollo's law: “...an organism cannot return, even partially, to a previous state already realized in its ancestral series." (Dollo 1893); it is likely to be very difficult to regain a flagellum, considering the large number of genes required to make a flagellum and that they would have to be regained from eukaryotes, where genes related to a function normally are not physically clustered (and therefore not introduced as islands of genes). Thus, the red algae are not very successful contributors to global oceanic photosynthesis... or are they? It could be argued that photosynthesis of red algal origin dominates the marine environment through organisms that evolved following a secondary endosymbiosis involving a red alga; these organisms would include diatoms, haptophytes, cryptophytes and to a minor extent brown algae. In fact, seven out of eight major eukaryotic taxa in the ocean uses a plastid of red algal origin (Falkowski et al. 2004). So the red algae broke the law by entering into a secondary endosymbioses with a flagellated hosts, regaining the flagellum and conquered the oceans.

Gene loss in red algae make them interesting models to probe eukaryotic genome evolution and address questions concerning why some organisms have very large genomes, like the flower Paris japonica which has a genome size of $150 \mathrm{~Gb}$ (Pellicer et al. 2010), while for others the genome is relatively small (the Arabidopsis thaliana genome is a thousand times smaller than the $P$. japonica genome). There are also indications that this gene loss was accompanied by a loss of introns (Collén et al. 2013). Most red algae have few introns, with the exception of Galdieria sulphuraria (Schönknecht et al. 2013). However, no present study has examined the evolution of introns in red algae, which, in my opinion, is likely to be very interesting. We probably need more new genomes from rhodophytes before this can be done, but see Bhattacharya et al. (2015).

Another interesting fact highlighted by the authors is that the red algal genomes thus far sequenced are predicted to code for relatively few genes $(<10,000)$ compared to other eukaryotes of similar complexity; for example, relative to green and brown macroalgae. The low number can be partially explained by the ancestral loss. Related to this, we still don't know why most red algal gene families are small and that there are no traces of gene duplications, to my knowledge.

There are also some practical advantages for the researcher in working with organisms that have a reduced gene set and small gene families. For example, transcriptomic analysis is easier with organisms having small gene families since short cDNA sequences can be aligned with more certainty to unique genes. It would also facilitate work on gene manipulation since the interpretation of phenotypes in specific gene knockouts would not be complicated by overlapping functions encoded by paralogous genes.

To conclude, the article of Qui et al (2015) shows the massive gene loss associated with the early evolution red algae and associates functionalities with a number of those losses, which also explains 
why red algae do not swim. At this point, we know what happened and when it happened, but the remaining question is WHY? The authors don't give any in depth explanation and I don't have one either... the conundrum remains, but we are generating more and more clues.

\section{References}

Bhattacharya, D., Qiu, H., Price, D. C. \& Yoon, H. S. 2015. Why we need more algal genomes. J. Phycol. 51:1-5.

Bloodgood, . RA. 2010. Sensory reception is an attribute of both primary cilia and motile cilia. J. Cell Sci. 123:505-509.

Collén, J., Porcel, B., Carre, W., Ball, S. G., Chaparro, C., Tonon, T., Barbeyron, T., et al. 2013. Genome structure and metabolic features in the red seaweed Chondrus crispus shed light on evolution of the Archaeplastida. Proc. Natl. Acad. Sci. USA 110:5247-52.

Dollo, L. 1893. Les lois de l'évolution. Bull. Soc. Belge Geol. Pal. Hydr. 7:164-166.

Falkowski, P. G., Katz, M. E., Knoll, A. H., Quigg, A., Raven, J. A., Schofield, O. \& Taylor, F. J. R. 2004. The evolution of modern eukaryotic phytoplankton. Science 305:354-360.

Hoffmann, L. 1989. Algae of terrestrial habitats. Bot. Rev. 55:77-105.

Koumandou, V. L., Wickstead, B., Ginger, M. L., van der Giezen, M., Dacks, J. B. \& Field, M. C. 2013. Molecular paleontology and complexity in the last eukaryotic common ancestor. Crit. Rev. Biochem. Mol. Biol. 48:373-396.

Moran, J., McKean, P. G. \& Ginger, M. L. 2014. Eukaryotic flagella: variations in form, function, and composition during evolution. BioScience 64:1103-1114.

Pellicer, J., Fay, M. F. \& Leitch, I. J. 2010. The largest eukaryotic genome of them all? Bot. J. Linn. Soc. 164:10-15.

Pickett-Heaps, J. D., West, J. A., Wilson, S. M. \& McBride, D. L. 2001. Time-lapse video microscopy of cell (spore) movement in red algae. Eur. J. Phycol. 36:9-22.

Qiu, H., Price, D. C., Yang, E. C., Yoon, H. S. \& Bhattacharya, D. 2015. Evidence of ancient genome reduction in red algae (Rhodophyta). J. Phycol.

Schönknecht, G., Chen, W. H., Ternes, C. M., Barbier, G. G., Shrestha, R. P., Stanke, M., et al. 2013. Gene transfer from bacteria and archaea facilitated evolution of an extremophilic eukaryote. Science 339:1207-1210.

Yoon, H. S., Hackett, J. D., Ciniglia, C., Pinto, G. \& Bhattacharya, D. 2004. A molecular timeline for the origin of photosynthetic eukaryotes. Mol.Bio. Evol. 21:809-818. 